\title{
STRATEGI KOMUNIKASI POLITIK (KAMPANYE) YANG DILAKUKAN OLEH PASANGAN CALON DRS. H. T. IRFAN TB DAN TGK. YUSRI JELANG PEMILIHAN UMUM KEPALA DAERAH TAHUN 2017 DI KABUPATEN ACEH JAYA
}

\author{
Aminah \\ Fakultas Ilmu Sosial dan Ilmu Politik, Universitas Teuku Umar \\ aminahaneukpanga@gmail.com
}

\begin{abstract}
This research aims to explain about political Communication Strategy (the campaign) what is done by the success team and the couple Drs. H. T. Irfan TB and Tgk. Yusri so elected as about and proceeding from the in the district of Aceh Jaya 2017-2022 period. Data required in this study was obtained through literature and field research. The research literature is done by reading textbooks, legislation, and other reading materials related to this research. While the field research conducted by interviewing informants. The results of the study showed that there are various strategies that done by the candidate pair Drs. H. T. Irfan TB and Tgk. Yusri. Now the political communication strategies that applied namely (1) makes the program hands out scholarships the son of Aceh Jaya smartphone continued as the vision and mission for the period 2017-2022. (2) Running through the Aceh Party (3) Making the former GAM a successful team. (4) Establishment of successful sub-district and village level teams. (5) Good cooperation between party bearers and supporting parties. (6) Quality of products offered at the time of the campaign. (7) Vehicles used in the conduct of the political marketing through advertising and campaigns.
\end{abstract}

Keywords: Strategy, Political Communication and the Election

\section{A. Latar Belakang}

Komunikasi politik (political communication) merupakan komunikasi yang melibatkan aktor-aktor politik serta menyampaikan pesan-pesan politik, atau berkaitan dengan kekuasaan, pemerintahan, dan kebijakan pemerintah. Di Indonesia pada saat ini momen-momen politik begitu banyak terjadi yang melibatkan seluruh masyarakat untuk ikut berpartisipasi di dalamnya seperti pada pemilihan umum secara langsung anggota legislatif (Pileg), pemilihan langsung Presiden (Pilpres) dan pemilihan langsung kepala daerah (Pemilukada). (Aminah, 2016:175).

Pemilukada merupakan ajang pemilihan yang sering kali dijadikan sebagai pesta demokrasi rakyat yang juga selalu dinantikan oleh masyarakat di setiap daerah. Melalui adanya partisipasi masyarakat, diharapkan pemilukada ini dapat berjalan secara Langsung, Umum, Bebas, Rahasia, jujur dan adil. Menjelang pemilukada di Kabupaten Aceh Jaya setiap pasangan calon yang sudah mendeklarasikan diri sebagai pasangan calon kepala daerah Kabupaten Aceh Jaya mulai menyusun rencana untuk melakukan kampanye agar dapat menjadi perhatian setiap masyarakat serta mendapatkan dukungan dari masyarakat Aceh Jaya dalam memimpin Aceh Jaya lima tahun ke depan.

Secara umum istilah kampanye adalah menampilkan suatu kegiatan yang bertitik tolak untuk membujuk seseorang agar mau dan mengikuti apa yang dikampanyekan. Leslie B.Snyder menyebutkan bahwa Kampanye merupakan aktivitas komunikasi yang terorganisasi, secara langsung ditujukan kepada khalayak tertentu pada periode waktu yang telah ditetapkan untuk 
mencapai tujuan tertentu. Dalam hal pemilukada di Kabupaten Aceh Jaya setiap pasangan calon memiliki strategi-strategi yang dilakukan oleh masing-masing pasangan calon baik oleh Tim pemenangan maupun simpatisannya. Hal ini dilakukan untuk mendapatkan dukungan yang sebanyak-banyaknya dari masyarakat di wilayah Kabupaten Aceh Jaya. Pada Pemilukada yang serentak dilakukan di Kabupaten Aceh Jaya mendapatkan dua pasangan Calon Bupati (Cabup) dan Calon Wakil Bupati (Cawabup) yang memenuhi persyaratan untuk maju sebagai pasangan Calon. Adapun yang menjadi kandidat Cabup dan Cawabup kabupaten Aceh jaya (Aminah, 2017:113) adalah sebagai berikut:

1. Pasangan Drs. H. T. Irfan TB dan Tgk. Yusri.S (Yang diusung oleh Partai Aceh dan Partai Demokrat dan partai pendukung yaitu Gerindra, PKS, PDIP, PAN, Nasdem, PPP, Hanura, PKB dan Partai Bulan Bintang).

2. Ir. Junaidi (Yah Gam) dan Bustami Syarbini, S.T (Yang diusung oleh Partai Golkar, PNA, PDA, PKPI dan partai pendukung yaitu Partai Idaman).

Dari kedua pasangan Cabup dan Cawabup Kabupaten Aceh Jaya ini menarik untuk dikaji yaitu pasangan Drs. H. T. Irfan TB dan Tgk. Yusri. Hal ini disebabkan karena pasangan ini memiliki kemenangan yang mutlak pada saat pemilihan umum kepala daerah yang bertepatan pada tanggal 15 April 2017 yang lalu. Kajian ini lebih memfokuskan kepada Strategi kampanye apa yang di lakukan oleh Pasangan Drs. H. T. Irfan TB dan Tgk. Yusri sehingga terpilih sebagai Cabup dan Cawabup di Kabupaten Aceh Jaya periode 2017-2022?

\section{B. Kerangka Teori}

Dalam kajian ini, penulis menggunakan teori-teori yang relevan dari berbagai literatur khususnya tentang Komunikasi, kampanye dan Kampanye dalam sistem komunikasi.

\section{Komunikasi}

Istilah "komunikasi" (Bahasa Inggris "communication") berasal dari bahasa Latin "communicates" atau "communication" atau "cummunicare" yang berarti "berbagi" atau "menjadi milik bersama". Dengan demikian, kata komunikasi menurut kamus bahasa mengacu pada suatu upaya yang bertujuan untuk mencapai kebersamaan (Riswandi, 2009: 1). Joseph A.Devito (1978) dalam bukunya "Communicologi: An Introduction to The Study of Communication" menjelaskan bahwa komunikasi adalah kegiatan yang dilakukan seseorang atau lebih dari kegiatan menyampaikan dan menerima pesan komunikasi yang terganggu keributan, dalam suatu konteks, bersama dengan beberapa efek yang timbul dari kesempatan arus balik (Lubis, 2005:10). Menurut Bernard Berelson dan Gary A. Steiner komunikasi merupakan suatu proses penyampaian informasi, gagasan, emosi, keahlian, dan lain-lain melalui penggunaan simbol-simbol seperti kata-kata, gambar, angka-angka, dan lainnya. Sedangkan menurut Weaver Komunikasi adalah seluruh prosedur melalui mana pikiran seseorang dapat mempengaruhi pikiran orang lainnya (Riswandi, 2009: 2).

Shannon dan Weaver (1949) bahwa komunikasi adalah bentuk interaksi manusia yang saling pengaruh mempengaruhi satu sama lainnya, sengaja atau tidak sengaja. Komunikasi tidak terbatas pada bentuk komunikasi menggunakan bahasa verbal, tetapi juga dalam hal ekspresi muka, lukisan, seni, dan teknologi. Oleh karenanya, jika kita berada dalam suatu situasi berkomunikasi, maka kita memiliki beberapa kesamaan dengan orang lain, seperti kesamaan bahasa atau kesamaan arti dari simbol-simbol yang digunakan dalam berkomunikasi (Cangara, 2007: 19-20). 


\section{Kampanye}

Pfau dan Parot (Venus, 2004:8) memberikan pengertian terkait Kampanye sebagai berikut: "campaign is conscious, sustained and incremental process designed to be implemented over a specified periode of time for the purpose of influencing a specified Audience" (kampanye adalah suatu proses yang dirancang secara sadar, bertahap dan berkelanjutan yang dilaksanakan pada rentang waktu dengan tujuan mempengaruhi masyarakat sebagai sasaran yang telah ditetapkan). Sementara menurut Kotler dan Roberto (1989) dalam Cangara (2009:284) kampanye adalah sebagai berikut: "a campaign is an organized effort conducted by one group (the change agent) which intends to persuade others (the target adopters), to accept, modify, or abandon certain ideas, attitudes, practices and behavior". (Kampanye ialah sebuah upaya yang dikelola oleh satu kelompok, (agen perubahan) yang ditujukan untuk mempersuasi target sasaran agar bisa menerima, memodifikasi atau membuang ide, sikap dan perilaku tertentu).

Berdasarkan defenisi tersebut maka setiap aktifitas kampanye setidaknya harus mengandung empat hal yakni: (1) Tindakan kampanye yang ditujukan untuk menciptakan efek atau dampak tertentu, (2) Jumlah masyarakat sebagai sasaran yang besar, (3) Biasanya dipusatkan dalam kurun waktu tertentu, dan (4) Melalui serangkaian tindakan komunikasi yang terorganisasi. Selain keempat hal tersebut, kampanye juga memiliki karakteristik lain, yaitu sumber yang jelas, yang menjadi penggagas, perancang, penyampai sekaligus penanggung jawab suatu produk kampanye, sehingga setiap individu yang menerima pesan kampanye dapat mengidentifikasi dan mengevaluasi kredibilitas sumber pesan setiap saat.

\section{Kampanye Dalam Sistem Komunikasi}

Terdapat beberapa macam pandangan tentang banyaknya komponen atau unsur yang mendukung terjadinya komunikasi. Aristoteles, ahli filsafat Yunani Kuno dalam bukunya Rhetorica menyebut bahwa suatu proses komunikasi cukup didukung oleh tiga unsur yang mendukungnya, yakni siapa yang berbicara, apa yang dibicarakan dan siapa yang mendengarkan (Cangara 2006:21). Awal tahun 1960-an David K. Berlo membuat formula komunikasi yang lebih sederhana. Formula itu dikenal dengan nama "SMCR", yakni: Source, Message, Channel dan Receiver. Kemudian Charles Osgood, Gerald Miller dan Melvin L. De Fleur menambahkan lagi unsur efek dan feedback. Perkembangan terakhir adalah munculnya pandangan dari Joseph de Vito, K. Sereno dan Erika Vora yang menilai faktor lingkungan merupakan unsur yang tidak kalah penting dalam proses komunikasi.

Konsep komunikasi klasik menyebutkan bahwa terdapat 5 komponen dalam berkomunikasi yaitu sebagai berikut:

1. Pengirim Pesan. Pengirim pesan adalah individu yang mengirim pesan. Dalam komunikasi antarmanusia, sumber bisa terdiri dari satu orang, tetapi bisa juga dalam bentuk kelompok misalnya partai, organisasi, atau lembaga.

2. Pesan. Pesan adalah sesuatu yang disampaikan pengirim kepada si penerima. Pesan ini dapat berupa verbal maupun nonverbal. Pesan secara verbal dapat secara tertulis maupun lisan. Pesan nonverbal dapat berupa isyarat, gerakan badan, ekspresi muka, dan nada suara.

3. Saluran atau Media. Saluran atau media adalah jalan/alur yang dilalui pesan dari si pengirim kepada si penerima. Saluran yang biasa dalam komunikasi adalah gelombang cahaya dan gelombang suara yang dapat kita lihat dan dengar. Media yang dimaksud di sini adalah alat yang digunakan untuk memindahkan pesan dari sumber kepada penerima.

4. Penerima Pesan. Penerima pesan adalah pihak yang menganalisis dan menginterpretasikan isi pesan yang diterimanya. Penerima bisa terdiri dari satu orang 
atau lebih, bisa dalam bentuk kelompok, partai atau negara. Penerima biasa disebut dengan berbagai istilah, seperti khalayak, sasaran, komunikan, atau dalam bahasa Inggris disebut audience atau receiver.

5. Lingkungan. Lingkungan atau situasi ialah faktor-faktor tertentu yang dapat mempengaruhi jalannya komunikasi. Faktor ini dapat digolongkan atas empat macam, yakni lingkungan fisik, lingkungan sosial budaya, lingkungan psikologis, dan dimensi waktu.

Kampanye memiliki berbagai macam tujuan, tetapi subyeknya ada dua yakni isu dan lembaga/organisasi. Pada isu ada tiga bentuk yakni 1) pengenalan isu, 2) persaingan memperebutkan isu dan 3) pengingatan kembali terhadap suatu isu. Pengenalan terhadap isu digunakan untuk memperkenalkan dan memberitahukan kepada semua pihak secara informatif. Informasi ini diberikan untuk menarik perhatian, meyakinkan kepada masyarakat tentang pentingnya isu tersebut untuk di perhatikan, supaya tidak terjadi bencana di kemudian hari. Untuk itu, kampanye berbentuk pengingatan kembali terhadap suatu isu. Bagi isu yang masih relevan, maka kampanye dilakukan untuk memperkuat atau memantapkan lagi keberadaannya. Dalam melakukan kampanye, dengan sendirinya posisi lembaga atau organisasi yang mendukung menjadi ikut dikenal oleh masyarakat. Mereka menjadi mengetahui posisi lembaga tersebut dalam persoalan/ isu yang sedang dikampanyekan, apa saja yang telah dikerjakan dan sedang dilakukan oleh lembaga tersebut dan kemudian secara tidak langsung menilai kinerja lembaga tersebut. Jika dapat dimanfaatkan dengan baik, maka posisi isu dan lembaga akan semakin kuat. Hanya seringkali yang terjadi, isunya lenyap, lembaganya ikut lenyap. Dapat juga isunya lenyap, tetapi nama lembaganya yang lebih terkenal. Melihat banyaknya kasus tersebut, mengindikasikan pentingnya keberlanjutan pengelolaan manajemen lembaga sejalan dengan pengelolaan kampanye.

\section{Metode}

Metode yang digunakan dalam penelitan ini yaitu metode kualitatif deskriptif. Teknik pengumpulan data dilakukan dengan dua cara yaitu studi kepustakaan dan ke lapangan. Studi kepustakan dilakukan dengan mencari berbagai referensi yang mendukung terhadap kasus yang diangkat. Sedangkan ke lapangan dengan observasi serta melihat, memantinformasi terkait strategi komunikasi politik (Kampanye) yang dilakukan oleh pasangan calon Drs. H. T. Irfan TB Dan Tgk. Yusri Jelang Pemilihan Umum Kepala Daerah Tahun 2017 Di Kabupaten Aceh Jaya.

\section{Pembahasan dan Analisis}

Menjelang pemilukada, partai politik dan masing-masing pasangan calon mempersiapkan diri untuk merebut simpati publik dengan berbagai macam strategi. Sebuah strategi biasanya mengacu pada rencana yang menyeluruh dan mencakup serangkaian tindakan yang langsung diarahkan pada pencapaian tujuan. Dalam upaya pencapaian tujuan tersebut, sebuah tindakan perlu mencapai konsep dan strategi tertentu. Tanpa disertai dengan konsep dan strategi yang tepat, para elit politik atau pasangan calon tidak akan mampu meraih simpati pemilih agar memilih kandidat yang diusungnya.

Berbagai macam cara atau strategi yang dilakukan oleh pasangan calon Drs. H. T. Irfan TB Dan Tgk. Yusri untuk mencari simpatisan serta dukungan dari berbagai kalangan masyarakat kabupaten Aceh Jaya yang akan menjadi para memilih baik sebagai pemilih pemula maupun masyarakat yang sudah pernah melakukan pemilihan sebelumnya. Hal ini dilakukan dengan cara menawarkan beberapa Visi dan misi serta pencitraan yang lainnya yang dibangun untuk mendapatkan kepercayaan yang penuh seluruh lapisan masyarakat kabupaten Aceh Jaya. Berikut merupakan langkah-langkah atau strategi-strategi komunikasi politik yang ditempuh oleh pasangan kandidat pasangan calon Drs. H. T. Irfan TB Dan Tgk. Yusri, diantaranya yaitu: 


\section{Menjadikan Program Beasiwa anak Aceh Jaya Cerdas Lanjutan Sebagai Visi dan Misi Untuk Periode 2017-2022}

Pasangan calon Drs. H. T. Irfan TB Dan Tgk. Yusri merupakan kandidat yang memiliki visi yang sama yang pernah dijalankan oleh pasangan incumbent sebelumnya yaitu Ir. Azhar Abdurrahman (periode 2006-2012 dan periode 2012-2017) yang memiliki basis grass root yang kuat dengan menjalankan program Beasiwa anak Aceh Jaya Cerdas. Program Beasiwa anak Aceh Jaya Cerdas diputuskan pada Juli 2008 dan dijalankan pada akhir 2010. Program Beasiwa anak Aceh Jaya Cerdas adalah salah satu bentuk aplikasi kinerja pemerintah Aceh Jaya untuk mencerdaskan putra putri Aceh jaya dengan memberikan beasiswa kepada setiap pelajar mulai dari tingkat Pendidikan Anak Usia Dini (PAUD), Taman Kanak-kanak (TK), Sekolah Dasar (SD), Sekolah Tingkat Pertama (SMP), Sekolah Menengah Atas (SMA), Diploma/Sarjana (D1-D4/S1) Magister (S2) hingga pendidikan Doktor (S3).

Jumlah beasiswa yang diberikan berdasarkan tingkat pendidikan yang ditempuhnya. Berikut rinciannya:

$\begin{array}{ll}\text { 1. } & \text { PAUD } \\ \text { 2. } & \text { SD } \\ \text { 3. } & \text { SMP } \\ \text { 4. } & \text { SMA } \\ \text { 5. } & \text { D1-S1 } \\ \text { 6. } & \text { S2-S3 dalam negeri } \\ \text { 7. } & \text { S1 Luar Negeri } \\ \text { 8. } & \text { S2-S3 Luar Negeri }\end{array}$

$$
\begin{gathered}
\text { : Rp. } 350.000 / \text { Orang } \\
\text { : Rp. 500. 000/ Orang } \\
\text { : Rp. 700. 000/ Orang } \\
\text { : Rp. } 1.000 .000 / \text { Orang } \\
\text { : Rp. 1.500. 000/ Orang } \\
\text { : Rp. 3.000. 000/ Orang } \\
\text { : Rp. 3.000. 000/ Orang } \\
\text { : Rp. 5.000. 000/ Orang }
\end{gathered}
$$

Pemerintah kabupaten Aceh Jaya menganggarkan dana sebanyak 10,500 Milyar setiap tahunnya untuk program beasiswa tersebut. Beasiswa ini bersumber dari dana Anggaran Pendapatan dan Belanja Kabupaten (APBK) Aceh Jaya. Hal ini dilakukan oleh pemerintah kabupaten Aceh Jaya untuk meningkatkan kualitas sumber daya manusia (SDM) Aceh Jaya melalui program Beasiwa anak Aceh Jaya Cerdas. Hal ini diisukan sebagai kinerja politik Azhar Abdurrahman dan kadernya yang akan melanjutkan program tersebut adalah pasangan calon no urut I pada pemilukada Aceh Jaya yaitu pasangan Drs. H. T. Irfan TB Dan Tgk. Yusri. Program pro rakyat tersebut dilakukan untuk mendapatkan perhatian dari masyarakat Aceh Jaya dan menjadi strategi politik untuk memperoleh kepercayaan (trust) dari masyarakat kabupaten Aceh Jaya. Program ini merupakan salah satu program yang ditawarkan Drs. H. T. Irfan TB Dan Tgk. Yusri selain dari memperbaiki infrastruktur pemerintahan dengan pembangunan Aceh Jaya pasca konflik dan Tsunami Aceh yang telah memporak-porandakan Aceh Jaya.

Program Beasiwa anak Aceh Jaya Cerdas tersebut disambut baik oleh seluruh masyarakat kabupaten Aceh Jaya. Ini merupakan salah satu senjata yang paling ampuh untuk menarik simpatisan serta dukungan dari masyarakat kabupaten Aceh Jaya. Program ini mendapat dukungan dari berbagai pihak baik ditingkat masyarakat desa, kecamatan, kabupaten, ditingkat di provinsi Aceh bahkan ditingkat nasional memberikan apresiasi kepada Bupati Aceh Jaya atas keberhasilannya dalam menjalankan programnya tersebut.

Pasangan calon urut 1 Drs. H. T. Irfan TB Dan Tgk. Yusri sepakat untuk kembali menjadikan program Beasiwa anak Aceh Jaya Cerdas sebagai salah satu Visi dan Misinya kedepan dalam membangun Aceh Jaya kedepan. Karena menurutnya Aceh Jaya masih sangat sedikit akan SDM yang diharapkan untuk dapat memajukan Aceh Jaya kedepan. Dengan memberikan beasiswa ini, diharapkan siswa dan para pelajar dapat termotivasi untuk menempuh pendidikan setinggi-tingginya. Sehingga Aceh Jaya selain memiliki berbagai Sumber Daya Alam 
(SDA) juga memiliki SDM yang dapat mengelola SDA yang ada di Aceh Jaya.

\section{Mencalonkan Diri Melalui Partai Aceh}

Selain dengan menawarkan program-program unggulan seperi Beasiwa anak Aceh Jaya Cerdas, Drs. H. T. Irfan TB Dan Tgk. Yusri juga merupakan kandidat yang diusung oleh Partai Aceh (PA) yang merupakan partai lokal pertama yang mendapatkan 36,4\% kursi dari tahun 2006. Pasangan Drs. H. T. Irfan TB Dan Tgk. Yusri ini dinilai memiliki hubungan baik dengan para Eks kombatan GAM sehingga mempengaruhi strategi politik yang dijalankan. Secara implisit bahwa pasar politik di Aceh Jaya pasca konflik dikuasai oleh pihak Eks GAM, sehingga membangun atau mendapat dukungan dari Eks GAM menjadi nilai tambah dalam melakukan pemasaran politik. Hal ini didukung oleh setting masyarakat post-konflik.

Masyarakat Aceh Jaya masih rentan dengan isu-isu konflik, nilai psikologis menjadi salah satu gambaran umum yang tidak dapat diajak untuk lebih terbuka dalam menentukan arah pemerintahan yang lebih rasional. Masyarakat Aceh Jaya masih dalam masa transisi untuk mencari jatidiri untuk bernegara. Disini, peran aktor politik menjadi pegangan bahkan referensi dalam menyuarakan aspirasi politik. Masyarakat Aceh Jaya mempercayai bahwa PA dapat menjaga perdamaian Aceh yang telah diperundingkan di Helsinki pada tahun 2005 silam. Hal ini tentu saja sangat menarik dukungan masyarakat yang sebahagian besar masyarakat Aceh jaya kehilangan harta benda serta keluarganya pasca konflik yang berkepanjangan di Aceh. Dengan melahirkan isu tersebut sebahagian masyarakat Aceh Jaya tentu tidak mau berpaling dari partai lokal yang satu ini. Mereka merasakan bahwa partai Aceh lah yang dapat menjaga perdamaian Aceh untuk kedepannya. Dan partai ini tentu harus mendapatkan dukungan dari masyarakat agar dapat bertahan di parlemen sehingga setiap pemilu dilakukan partai lokal yang ada di Aceh khususnya PA tidak akan hilang. Karena ini merupakan salah satu bentuk hasil dari perundingan antara RI dan GAM.

\section{Menjadikan Eks GAM Sebagai Tim Sukses}

Keberadaan Eks GAM dalam proses penyelenggaraan pemilihan kepala daerah ini sangat mempengaruhi pasangan Drs. H. T. Irfan TB Dan Tgk. Yusri dalam menentukan pemasaran politik. Tingkat pemasaran politik ini ditentukan bagaimana membangun komunikasi dengan Eks GAM yang ditemui dipasaran. Sehingga peran Eks GAM menjembatani kontestan untuk sampai pada masyarakat sebagai pemilih pada saat pilkada dilaksanakan. Selain itu, Sistem komunikasi politik merupakan proses mobilisasi yang dilakukan calon kandidat dalam membahasakan produk politik yang dipasarkan kepada masyarakat.

Hal penting yang perlu diperhatikan pada tahapan ini yaitu kesesuaian bahasa yang digunakan dengan tingkat pemahaman masyarakat pemilih. Untuk mengenali masyarakat pemilih, kontestan bisa melakukan pemetaan terhadap kelompok-kelompok masyarakat pemilih, agar memudahkan calon kandidat mengenali pintu masuk ke lingkungan masyarakat pemilih. Komunikasi politik yang dilakukan pasangan calon Drs. H. T. Irfan TB Dan Tgk. Yusri, tidak keluar dari background yang diusung dan runtutan dari platform partai pengusung pasangan calon ini. Sehingga kehadiran Drs. H. T. Irfan TB Dan Tgk. Yusri merupakan harapan masyarakat Aceh Jaya untuk terus melakukan perubahan-perubahan Aceh Jaya ke arah yang lebih baik dan sesuai dengan apa yang ditawarkan oleh pasangan calon ini.

Nilai kuasa Eks GAM memiliki kekhususan dalam sistem mobilisasi massa, tindak kekerasan menjadi senjata kekuasaan untuk mendapatkan hak pilih. Karena pasangan kandidat Drs. H. T. Irfan TB Dan Tgk. Yusri memiliki hubungan baik dengan Eks GAM, sehingga Kemenangan yang diperoleh merupakan bentuk partisipan Eks GAM dan bentuk aspirasi masyarakat untuk menghindari lahir kembali konflik di Aceh khususnya Aceh Jaya. Masyarakat 
Aceh Jaya mempercayai bahwa pasangan ini mampu untuk menata Aceh Jaya sesuai dengan apa yang dikampanyekan oleh kandidat pada saat kampanye untuk membawa Aceh Jaya bermartabat, Sejahtera dan benar-benar memperjuangkan aspirasi rakyat.

\section{Pembentukan Tim Sukses Tingkat Kecamatan dan Desa}

Pembentukan tim sukses dimulai dari pembentukan ketua sampai dengan kordinator lapangan tingkat desa dan kecamatan. Tugas dari tim sukses ini adalah untuk mensukseskan kandidat dalam memenangkan pemilukada. Keberadaan tim sukses sangat membantu dan menyukseskan pemilihan umum kepala daerah di kabupaten Aceh Jaya, karena tim sukses bekerja sama untuk membuat strategi dalam rangka menarik minat pemilih terhadap kandidat calon yang diusungnya untuk memenangkan pemilukada. Hal ini seperti yang dijelaskan oleh salah satu Tim Sukses pasangan kandidat Drs. H. T. Irfan TB Dan Tgk. Yusri, yaitu sebagai berikut:

"Pembentukan tim sukses dilakukan di tingkat kecamatan (pembentukan tim Sembilan). Penamaan tim Sembilan tersebut karena di kabupaten Aceh Jaya terdiri dari Sembilan kecamatan dan juga di tiap-tiap desa. Jika dalam satu desa penduduknya banyak, maka tim yang dibentuk lebih dari sepuluh orang bahkan sampai lima belas orang. Setiap tim yang sudah dibentuk menjalankan tugasnya masing-masing. Adapun tugas dari tim tersebut yaitu mendatangi rumahrumah warga untuk mendata keluarga yang akan memilih. Jika keluarga tersebut belum ada pilihan untuk dipilihnya maka tim ini akan menyarankan keluarga tersebut untuk memilih pasangan kandidat Drs. H. T. Irfan TB Dan Tgk. Yusri” (Ay, tim sukses pasangan kandidat Drs. H. T. Irfan TB Dan Tgk. Yusri, wawancara, 26 Juli 2017).

Kesuksesan dalam pemilukada juga tidak lepas dari berbagi peran-peran yang dilakukan oleh tim sukses untuk mendapat dukungan dari kalangan masyarakat. Peran tim sukses adalah membentuk tim dan melakukan berbagai kegiatan dalam rangka menyukseskan pemilihan pasangan kandidat Drs. H. T. Irfan TB Dan Tgk. Yusri dalam pemilukada. Tim sukses mengatur berbagai kegiatan-kegiatan dan tindakan-tindakan yang akan dilaksanakan. Tim juga wajib melaporkan kepada kandidat atas semua persoalan-persoalan yang dilaksanakan dalam kegiatan pemilukada. Tim sukses termasuk sebagai pelaksanaan pekerja dalam pemilukada dan juga penyampaian informasi kepada masyarkat atas keberhasilan Partai Aceh di kabupaten Aceh Jaya Sepuluh tahun silam pada saat Ir. Azhar Abdurrahman menjabat sebagai orang nomor satu di Aceh Jaya.

Dalam setiap tindakan untuk merealisasikan rencana menjadi hasil yang diharapkan, kandidat harus mengangkat orang-orang yang kreatif, proaktif, strategis, disiplin dan optimis di dalam sebuah tim sukses. Kecerdasan yang dimiliki pasangan kandidat Drs. H. T. Irfan TB Dan Tgk. Yusri untuk membangun tim sukses yang efektif akan sangat membantunya dalam kesuksesan menjelang pemilukada. Pasangan kandidat Drs. H. T. Irfan TB Dan Tgk. Yusri menetapkan tujuan utama tim sukses yaitu meraih dukungan dari berbagai kalangan. Pembentukan tim sukses yaitu orang-orang yang jujur, tidak menfitnah dan tidak menjelekjelekkan tim sukses dari kandidat lain. Tim sukses ini berperan juga untuk mencari dikungan suara sebanyak-banyaknya dari masyarakat.

\section{Kerja sama yang Baik Antar Partai Pengusung dan Partai Pendukung}

Strategi komunikasi politik pada dasarnya merupakan langkah-langkah dalam melakukan komunikasi politik yang berkaitan dengan pembuatan, penyebarluasan, penerimaan, dan dampakdampak informasi dalam politik, baik melalui interaksi antar manusia maupun media massa. Mulai dari yang sederhana dan bermodal ala kadarnya, seperti penggalangan suara dengan menyebarkan brosur-brosur, kartu pasangan calon dan ada juga dalam bentuk sumbangan sosial. Apapun dan bagaimanapun cara yang ditempuh, esensi yang hendak dicapai adalah terjalinnya 
komunikasi yang efektif dan efisien antara pasangan calon Drs. H. T. Irfan TB Dan Tgk. Yusri dengan para pemilih. Kemampuan pasangan calon Drs. H. T. Irfan TB Dan Tgk. Yusri dalam membaca dan memetakan karakteristik masing-masing masyarakat juga dibutuhkan.

Pasangan calon Drs. H. T. Irfan TB Dan Tgk. Yusri tidak hanya mengedepankan komunikatif tetapi lebih dari itu, yakni mampu menonjolkan keunggulan dan menutupi kelemahannya. Strateginya disusun sedemikian rupa dengan mempertimbangkan berbagai veriabel yang ada. Sehingga benar-benar sesuai dengan kondisi lingkunagan dan mampu menyentuh hati masyarakat di Kabupaten Aceh Jaya. Pasangan calon Drs. H. T. Irfan TB Dan Tgk. Yusri mengajak Tim yang telah dibentuk dari tiap-tiap desa untuk berdialog dengan masyarakat. Dalam dialognya tim sukses menjelaskan kepada masyarakat, jika terpilih pasangan calon Drs. H. T. Irfan TB Dan Tgk. Yusri sebagai bupati maka apa saja langkah-langkah pembangunan yang dibutuhkan oleh masyarakat dan kemudian tim ini dapat menyampaikannya kepada pasangan calon Drs. H. T. Irfan TB Dan Tgk. Yusri.

Dalam penerapan strategi-strategi tersebut kandidat tidak menggunakan media-media seperti televisi, radio dan koran. Pasangan calon Drs. H. T. Irfan TB Dan Tgk. Yusri memang orang yang sudah dikenal oleh masyarakat. Jabatannya yang pernah menjabat sebagai Sekda kabupaten Aceh Jaya di periode sebelumnya juga membuatnya tidak asing lagi di mata masyarakat kabupaten Aceh Jaya. Hal yang sama juga pada calon wakilnya yaitu Tgk. Yusri yang pernah menjabat sebagai ketua Baitul Mal Aceh Jaya.

Pada pemilukada 15 April 2017, Pasangan Drs. H. T. Irfan TB dan Tgk. Yusri.S diusung oleh Partai Aceh dan Partai Demokrat dan dari partai pendukung yaitu Gerindra, PKS, PDIP, PAN, Nasdem, PPP, Hanura, PKB dan Partai Bulan Bintang. Adanya koalisi antar partai politik yang dibangun berdasarkan platfom ideologi. Partai koalisi juga berperan dalam menyukseskan pemilukada. Peran dari partai-partai koalisi tersebut juga sangat membantu kesuksesan dalam memenangkan pemilukada oleh Pasangan Drs. H. T. Irfan TB dan Tgk. Yusri.S. hal ini seperti yang dijelaskan oleh YS, berikut adalah pernyataannya:

"Pasangan kandidat Drs. H. T. Irfan TB Dan Tgk. Yusri tidak bekerja sindiri untuk mencapai kemenangannya di pesta demokrasi kemarin. Pasangan ini melakukan berbagai hal untuk mencapai kemenangan seperti melakukan kerjasama dengan partai-partai yang mendukung atau sering disebut sebagai partai koalisi. Mereka ini bekerjasama untuk memenangkan pasangan Drs. H. T. Irfan TB Dan Tgk. Yusri. Ada sekitar 11 partai yang mengusung dan mendukung pasangan kandidat ini" (YS, tim sukses pasangan kandidat Drs. H. T. Irfan TB Dan Tgk. Yusri, wawancara, 27 Juli 2017).

Partai-partai yang mengusung dan mendukung pasangan calon yang akan maju sebagai pemimpin memiliki perannya tersendiri untuk memenangkan pasangan calon yang diusung dan didukungkannya. Peran partai yaitu bekerja sama dengan tim sukses. Partai sebagai alat pendukung dan menjembatani kandidat dalam pelaksanaan pemilukada sama halnya seperti tim sukses. Bedanya, tim sebagai rangkuman yang tidak terpisahkan dari partai manapun, sedangkan partai khusus.

\section{Kualitas Produk Yang Ditawarkan Pada Saat Kampanye}

Kualitas produk yang dibentuk dan ditawarkan merupakan salah satu nilai ukur terhadap keunggulan strategi dalam melakukan komunikasi politik (kampanye) yang dilakukan oleh pasangan calon Drs. H. T. Irfan TB Dan Tgk. Yusri. Keunggulan produk politik dalam tatanan kontestasi perpolitikan kabupaten Aceh Jaya didominasi oleh kesesuaian produk politik dengan ideologi partai. Produk politik yang dibentuk tidak hanya berdasarkan penjajakan pasar yang dilakukan pra desain produk, lebih kepada konsistensi ideologi pengusung dengan isu yang 
ditawarkan.

Menjaga perdamaian Aceh merupakan wujud kesejahteraan masyarakat Aceh Jaya, terkait kesepahaman MoU Helsinki pasca tsunami Aceh. Masyarakat Aceh Jaya jera sebagai orang yang pernah terlibat konflik yang panjang di Aceh Jaya. Hak pilih yang diberikan pada pemilihan Bupati/wakil Bupati untuk periode 2017-2022 merupakan antisipasi untuk tidak lahir konflik Aceh kembali. Dengan berbagai "gelombang besar" yang ditemui masyarakat pra pemilihan, dilain sisi disebutkan "intimidasi" merupakan sebuah phobia terhadap kelompok-kelompok tertentu. Nilai demokrasi yang terdapat di Aceh Jaya memiliki warna tersendiri, pemahaman demokrasi melebur sesuai situasi wilayah tersebut.

Demokrasi sesungguhnya tidak berjalan di Aceh Jaya. Pembajakan demokrasi kembali dipertonton oleh para Eks GAM, kekuasaan yang dimiliki menjadi sejata untuk memobilisasi massa dalam bentuk kekerasan. Masyarakat dihipnotis untuk mengakui bahwa proses pemilihan tersebut berjalan dibawah system demokrasi, keep silent terhadap black campaign yang dilakukan oleh kelompok dominan, dilihat sebagai bentuk safety. Kekuatan partai lokal dapat menghapus ruang partisipasi politik melalui jalur perseorangan. Kemenangan, dengan program mengembalikan pemerintahan kabupaten Aceh Jaya sesuai dengan kandungan MoU dan penerapan UUPA secara keseluruhan merupakan kunci terhadap penguatan partai politik lokal terkait pasal 256 ayat 1 , huruf d.

\section{Kendaraan Yang Dipakai dalam Melakukan Marketing Politik}

Adapun kendaraan yang dipakai untuk melakukan marketing politik dari kandidat calon bupati/wakil pasangan calon Drs. H. T. Irfan TB Dan Tgk. Yusri adalah sebagai berikut:

a. Iklan

Iklan yang dipasarkan berupa gambar-gambar/foto-foto calon kandidat dan wakil kandidat pasangan calon Drs. H. T. Irfan TB Dan Tgk. Yusri. Iklan ini dipasang ditempat-tempat yang dianggap strategis dan dilihat oleh banyak orang. Seperti di tempat pemasangan baliho. Gambar pasangan calon bupati/wakil bupati dicetak dalam berbagai ukuran. Mulai dari berbentuk kartu cart hingga poster yang besar yang dipasang setiap sudut jalan dan tempat-tempat yang diizinkan Kemite Independen Pemilihan (KIP) Aceh Jaya. Melalui iklan ini, kandidat calon bupati/wakil pasangan calon Drs. H. T. Irfan TB Dan Tgk. Yusri juga diikutsertakan ditulis program-program apa yang akan dikerjakan setelah menjabat nantinya selama lima tahun masa jabatannya. Tentunya untuk memajukan Aceh Jaya yang lebih baik.

b. Kampanye

Kampanye politik merupakan upaya yang terorganisir yang bertujuan untuk mempengaruhi proses pengambilan keputusan para pemilih dan kampanye politik selalu merujuk pada kampanye pada pemilihan umum. Baik pemilihan kepala daerah maupun pemilihan badan legislatif (DPRD)

Pesan dari kampanye yaitu menonjolan ide bahwa sang kandidat atau calon ingin berbagi dengan pemilih. Dalam kampanye politik yang dijalankan oleh pasangan kandidat calon bupati/wakil pasangan calon Drs. H. T. Irfan TB Dan Tgk. Yusri yaitu menyampaikan pesanpesan dari beberapa poin berbicara tentang isu-isu kebijakan yang akan ditetapkannya kedepan. Poin-poin ini dirangkum dari ide utama dari kampanye dan sering diulang untuk menciptakan kesan abadi kepada pemilih. Kandidat calon bupati/wakil pasangan calon Drs. H. T. Irfan TB Dan Tgk. Yusri akan selalu mencoba untuk membuat para kandidat atau calon lain menjadi "tanpa pesan" berkaitan dengan kebijakannya atau berusaha untuk pengalihan pada pembicaraan yang tidak berkaitan dengan poin kebijakan atau program. 


\section{E. Penutup}

Dari uraian di atas dapat disimpulkan bahwa Strategi Komunikasi Politik (Kampanye) Yang Dilakukan Oleh Pasangan Calon Drs. H. T. Irfan Tb dan Tgk. Yusri Jelang Pemilihan Umum Kepala Daerah Tahun 2017 Di Kabupaten Aceh Jaya terdapat berbagai macam strategi diantaranya yaitu (1) Menjadikan program beasiwa anak aceh jaya cerdas lanjutan sebagai visi dan misi untuk periode 2017-2022. (2) Mencalonkan diri melalui Partai Aceh (3) Menjadikan eks GAM sebagai tim sukses. (4) Pembentukan tim sukses tingkat kecamatan dan desa. (5) Kerja sama yang baik antar partai pengusung dan partai pendukung. (6) Kualitas produk yang ditawarkan pada saat kampanye. (7) Kendaraan yang dipakai dalam melakukan marketing politik yaitu melalui iklan dan kampanye.

Dari berbagai macam strategi yang dilakukan oleh Tim sukses dan pasangan calon Drs. H. T. Irfan TB Dan Tgk. Yusri membuktikan bahwa strategi yang digunakan oleh pasangan calon ini sangat tepat dan efektif. Hal ini terlihat dari kemenangan yang diraih oleh pasangan calon Drs. H. T. Irfan TB Dan Tgk. Yusri yang meraih suara terbanyak di berbagai kecamatan yang ada di Kabupaten Aceh Jaya.

\section{Daftar Pustaka:}

Aminah, 2016. Peran Media Dalam Komunikasi Politik Jelang Pemilihan Umum Kepala Daerah Tahun 2017 Di Kabupaten Aceh Barat. Source, Jurnal Ilmu Komunikasi. 2 (3): 175

Aminah, 2017. Peran Media Sosial "Facebook" Jelang Pemilihan Umum Kepala Daerah Tahun 2017 Di Kabupaten Aceh Jaya. Source, Jurnal Ilmu Komunikasi. 3 (1): 113

Antar, Venus. 2004. Manajemen Kampanye; Panduan Teoritis Dan Praktis Dalam Mengefektifkan Kampanye Komunikasi. Simbiosa Rekaatam Media. Bandung.

Astrid S. Susanto. 1980. Komunikasi Sosial di Indonesia. Bina Cipta. Bandung.

Cangara, Hafied. 2009. Komunikasi Politik: Konsep, Teori dan Strategi. Rajawali Pers. Jakarta.

Lubis, 2005. Pengantar Komunikasi Lintas budaya. Universitas Sumatera Utara. Medan.

Riswandi. 2009. Ilmu Komunikasi. Graha Ilmu. Jakarta.

Shanon and weaver. 1945. The Mathematical theory of Communication. University of Illinois Press. Urbana. 